\title{
Wage Inequalities: A Result of Different Levels and Fields of Tertiary Education?
}

\author{
DARJAN PETEK \\ UniCredit Bank, Slovenia \\ darjan.petek@gmail.com \\ TIMOTEJ JAGRIČ \\ University of Maribor, Slovenia \\ timotej.jagric@um.si
}

In this article we examine the impact of tertiary education on the amounts of wages in Slovenia for 2011. We use micro data from the statistical survey Structure of Earnings Statistics and micro data from the survey of graduates from tertiary education. We found out that there are significant differences in the amounts of wages as regards the level and field of education. Region and activity of the company where the person is employed also plays an important role in wage determination. Also the effects of gender and public/private sector are statistically significant. Using the average wage per hour as dependent variable gives similar results as the average annual wages.

Key words: wage inequalities, fields of study, level of education,

Mincer regression, returns to education https://doi.org/10.26493/1854-4231.12.59-73

\section{Introduction}

In Slovenia we can find several studies where the authors quantified the returns of education on the amounts of wages (Bevc 1993; Stanovnik 1997; Orazem and Vodopivec 1994; 1997; Ahčan, Polanec and Trunk-Širca 2006) but only two, which also examined the returns caused by the field of education (Ahčan, Polanec and Kozamernik 2008; Bartolj et al. 2012). The last one uses the annual wages and the annual net income from work as dependent variables. In the literature we can often find the fact that the hourly wages are more appropriate measurement, but the data sources are very scarce. People with higher education and males often work more than people with lower education or females and consequently they earn more. Due to this fact the hourly wages are considered as more appropriate measurement than the annual wages. In this paper we analyse both based on research presented in Petek (2016). 
On the global level, among many others, the returns of education were assessed by Münich, Svejnar, and Terrell (2005) in the Czech Republic, Walker and Zhu (2010) in the UK, Buonanno and Pozzoli (2009) for Italy and Livanos and Pouliakas (2008; 2009) for Greece.

In this paper, we have tested the hypothesis that there are significant differences in the amounts of wages due to different levels and fields of tertiary education. The main purpose of this paper is thus to prove this and additionally, to show other important factors (region, activity of the employer, gender and public/private sector) in wage determination. We decided to analyse Slovene data due to data availability based on good administrative data sources and local, well-known environment.

In the next section we present the theoretical concept of the issue we are tackling and briefly review the results of other empirical studies. In the third chapter, we present our database and sources that we have used for the data integration. In the fourth chapter the model which we used is shown. In the fifth chapter we interpret the obtained results and compare them with some of the analysis carried out so far. We are closing the paper in the final chapter, which summarizes the main results and conclusions of the analysis.

\section{Short Review of the Literature}

The impact of human capital on wages is usually estimated with $\mathrm{Hu}-$ man Capital Earnings Function, based on Mincer's model originating in the year 1974. This is the theory of James Mincer, the representative of the Chicago school of economics. Mincer's model or Mincer equation explains the wage amounts as a function of human capital. Many eminent economists (such as Barro and Sala-i-Martin 2003, 239) have demonstrated that the theory of human capital has a significant influence on the economic growth.

Before Mincer's article in 1958, the prevailing theory on the distribution of wages consisted mainly of luck in determining the financial success of an individual (Polachek 2007, 5-6). Such theories did not offer any economic rationale regarding the distribution of wages. By incorporating the concepts of the Adam Smith's theory of compensating differences together with the Friedman's notation of the possibility of various likelihood options of income distribution between employment alternatives, Mincer conceived an entirely new theory. His innovation was the recognition of the choice of individuals enabling revenues to be easily evaluated with the theory of human capital. Addressing education and occupation as investment opportunities meant an imaginative modelling of investments results. Assum- 
ing that individuals invest in education until investment costs are the same as the today's value of revenues due to involvement in schooling, allows easily feasible econometric specification, which led to the log-linear income function. Not only that this formulation provides a benchmark of private return rate of education, it is also easy to generalize experience gained after the end of schooling. This article showed that the wage of an employee consistently increases with a decreasing speed through the life cycle. Wage function represents a concave curve for most persons in paid employment. Human capital theory also explains the differences of gender, racial and ethnic diversity, geographical and occupational mobility, occupation, unemployment and other characteristics of the labour market.

Education plays a major role in the modern labour market (Card 1999). A large amount of studies in different countries and at different times confirmed that more educated individuals compared to less educated ones receive higher wages and experience less unemployment. Their occupations are considered to be more prestigious. Despite a lot of convincing evidence on the positive correlation between education and status in the labour market, social scientists are cautious about the conclusions on the causal effect of education. Without the empirical evidence it is very difficult to know whether the observed higher wages of better educated employees are caused by their higher level of education or did the individuals with the 'capacity of attaining higher wages' chose to acquire higher education.

Education and experience are the most commonly used dimensions of human capital. We can easily find papers which measured the impact of educational level (duration of schooling), also in Slovenia. Research in Slovenia was performed by Bevc (1993), Stanovnik (1997), Orazem and Vodopivec (1997), Vodopivec (2004; 2006), Ahčan, Polanec and Trunk-Širca (2006) and Ahčan, Polanec and Kozamernik (2008). The overall findings of these studies (as in other countries that have gone through the transition process) are that returns from higher education increase, but not proportional with the level (length) of education. Due to this fact the income inequality of the population increased. Research for other national economies are of course very common. Harmon, Walker and Westergaard-Nielsen (2001), Becker (1993), Ehrenberg and Smith (2000), Angris and Krueger (1991; 1992), Card (1999), Conneely and Uusitalo (1997) are only a few of them which we found during the preparation of this paper (for more detailed description see Petek 2016). Most of them used the instrumental characteristics of the school system as a source of credible information of the causal ef- 
fect of education and represents one of the most important research directions in recent literature. In general, they found that the IV estimates of private returns of education are consistently above the corresponding oLs estimates - often by $30 \%$ or more. Card (1999, 1841) believes that the instrumental variables such as compulsory schooling or the proximity of schools are likely to influence the decisions of individuals, who would otherwise have relatively low levels of education, to obtain higher levels of education. If these individuals have relatively higher marginal returns than average, then the estimates of such instrumental variables can yield higher estimates of returns than the corresponding ols. A necessary condition for this phenomenon is that the marginal rate of returns of schooling are negatively correlated with the level of education among the population.

Boarini and Strauss $(2010,21)$ provide estimates of private internal rates of return to tertiary education for $21 \mathrm{OECD}$ countries in the period 1991-2005. They used cross-sectional regressions based on individual data from international panel data sources. They calculated returns which are on average above $8 \%$.

The private returns estimates of different fields of education are scarse also at global level. For Slovenia, we found two. The last one was published in 2012 (Bartolj et al. 2012) and uses the net annual wages and the annual net income from work as dependent variables. They found significant differences in the rates of returns for different levels of education and for different fields of education. Card (1999), in contrast, observed a constant rate of private returns for all fields of education in the United States. Outside Slovenia there were similar surveys conducted by Walker and Zhu (2011) in the UK, Buonanno and Pozzoli (2009) for Italy and Livanos and Pouliakas (2008; 2009) for Greece. A common finding in them is that there are significant differences in private return rates by fields of study, although this is not always the case. Walker and Zhu (2010) found that in the uK this is not true for women.

\section{Data Description and Descriptive Statistics}

The database, which was analysed in this article consists of all employees who have obtained tertiary level of education in the period between 1989 and 2011 and were working for the same employer (full-time) the whole year of 2011. Slovenia was at that time at the beginning of economic recession. The main data source represents micro data from the statistical survey Structure of Earnings Statistics, which is based solely on the existing administrative sources, 
i.e. data on earnings from the Tax Administration of the Republic of Slovenia and demographical data on persons in paid employment from the Statistical Register of Employment (SRE). This data source contains information on the annual gross and net wage, income tax, social security, gender, age, level of education, level and field of educational attainment, activity, region, municipality and sector (public/private) of enterprises or establishments where an employee performs work (Divjak 2011). Since the data on educational attainment in SRE is of lower quality (the source are $M$ forms for health insurance which are filled out by the employer's human resources staff), we collected data on educational attainment obtained from the statistical survey of graduates from tertiary education. In addition to the data on educational attainment further information were available to us: year of graduation, college, study program, type and educational field (Kozmelj 2014). Because we want to estimate the average wages per hour (this information is not in the personal income tax and, consequently, not in the statistical survey Structure of Earnings Statistics), we used aggregated data (at the section level of NACE Rev. 2) on paid hours from the Survey on hours worked. We had access to micro data in the secure room of the Statistical Office. The database was compiled from the two data sets with micro data (structural statistics on earnings and data on graduates) and the two data sets of aggregates (paid hours and unemployment rates). The database does not include registered natural persons (individual private entrepreneurs and persons engaged in professional activities (lawyers, doctors, notaries), because they do not receive wages). Integrated database thus contains 131,069 observations.

We are using four measurements of wages i.e. the annual gross and net wages and gross and net wages per hour. Since data on work experience of employees is not available, we used the potential work experience. We calculated potential work experience as the age of person in paid employment in year 2011 minus education duration in years minus the age of school entry ( 7 years - which was the normal age of a person at entry into the education system in Slovenia for the persons observed). The original idea to make an approximation of the potential work experience using the person's age at year 2011 and subtracting the year of graduation has proved to be inaccurate and biased (many employees obtained tertiary education in the course of employment, and therefore such an estimate underestimates their real work experience).

The average person in paid employment in the target population is 38.54 years old and has 15.96 years of work experience. Average 
TABLE 1 Descriptive Statistics

\begin{tabular}{lrrlrr}
\hline Average age & 38.54 & & Average hourly gross wage & 13.28 \\
Media age & 38 & & Median hourly gross wage & 11.67 \\
sD age & 7.76 & & sD hourly gross wage & 7.76 \\
\cline { 1 - 2 } \cline { 5 - 6 } Average work experience & 15.96 & & Average annual net wage & 16,474 \\
Median work experience & 15 & & Median annual net wage & 15,208 \\
sD work experience & 7.81 & & sD yearly annual net wage & 7,641 \\
\cline { 6 - 7 } Average annual gross wage & 26,748 & & Average hourly net wage & 8.18 \\
Median annual gross wage & 23,460 & & Median hourly net wage & 7.55 \\
sD yearly annual gross wage & 15,591 & & sD hourly net wage & 3.78 \\
\hline
\end{tabular}

NOTES Number of observations $=131,069$. Based on data from sors (http://www.stat .si/statweb).

gross and net earnings for persons with tertiary education amounted EUR 26,748 and 16,474 EUR per year, respectively. The average annual gross (net) wage per hour amounted EUR 13.28 (EUR 8.18).

In our data, $58.9 \%$ of the population are women. Of these, the majority is employed in the field of social sciences, business and law $(49.16 \%)$ and education (17.98\%). On the other hand, the majority of male employees is employed in engineering, manufacturing and construction $(33.76 \%)$ and in the social sciences, business and law (33.59\%). Irrespective of gender, the most persons in paid employment are employed in the field of social sciences, business and law $(42.76 \%)$ and in engineering, manufacturing and construction (17.10\%). Most of those who were employed in 2011 and have obtained tertiary education after 1989, had completed Academic higher education (former) (40.98\%), followed by employees who have completed Professional higher education (former) (26.66\%). Academic higher education (former) had $36.49 \%$ (63.51\%) of men (women), Professional higher education (former) had $39.01 \%$ (60.99\%) of men (women). Women with completed Master of science (former) were slightly in majority $(51.35 \%)$. On the other hand, the gender ratio for Doctorate of science (former) is significantly better for men (58\% against $42 \%$ ).

The comparison of wages by field of activity NACE Rev. 2 shows that the majority of people with tertiary education is employed in Education ( $\mathrm{P}-19.43 \%)$, Public administration and defence, compulsory social security $(\mathrm{O}-14.99 \%)$ and Manufacturing (13.18\%). The proportion of women is the highest in Human health and social work activities ( $\mathrm{Q}-81.04 \%)$ and Education ( $\mathrm{P}-78.20 \%)$, while the proportion of men is the highest in the Electricity, gas, steam and air conditioning supply $(\mathrm{D}-79.65 \%)$ and Mining and quarrying $(\mathrm{C}-70.72 \%)$. 
Among men, the most persons in paid employment work in Manufacturing (C - 19.72\%) and Public administration and defence, compulsory social security $(\mathrm{O}-15.14 \%)$, while the majority of women work in Education $(\mathrm{P}-25.80 \%)$ and Public administration and defence, compulsory social security $(\mathrm{O}-14.89 \%)$.

$54.98 \%$ of the observed population works in the private sector, $45.02 \%$ in the public sector. The gender structure of persons with tertiary education is very balanced in the private sector, $(50.81 \%$ men), in the public sector the proportion of women with tertiary education is significantly higher $(70.71 \%)$.

\section{Model}

In this paper we use the least squares method and Mincer's model (Petek 2016). In his model the natural logarithm of wages is expressed as a linear function of education (duration of schooling in years) and a quadratic functions of work experience (Mincer 1974, 83-4).

\section{MINCER EQUATION}

$$
\ln w_{i}=\beta_{\mathrm{o}}+\beta_{1} s_{i}+\beta_{2} x_{i}+\beta_{3} x_{i}^{2},
$$

where $w_{i}$ are wages of a person $i, s_{i}$ stands for involvement in education in years, and $x_{i}$ is work experience. Work experience is a proxy for human capital accumulation that occurs after the completion of formal education. Due to unavailability of data on work experience, we used the potential work experience. We calculated it by deducting the length of schooling and additional 7 years (which was the normal age of entry into the education system in Slovenia for the persons observed) from the age of persons in paid employment in year 2011. Quadratic function of education is introduced in the model in order to allow a possible decrease in private returns during the life cycle of an individual. Technological change may lead to a situation where gained experience in the past become useless.

In the literature of Human Capital Earnings Function many different dimensions to measure wages were analysed: yearly, monthly, and hourly and almost always in a logarithmic form. The popularity of the logarithm function reflects many factors (Card 1999). The distribution of logarithmic wages (especially the logarithmic hourly wages) is surprisingly close to normal distribution. Another practical reason for using the logarithmic transformation is the evident success of the standard (semi-logarithmic) Human Capital Earnings function. 
Darjan Petek and Timotej Jagrič

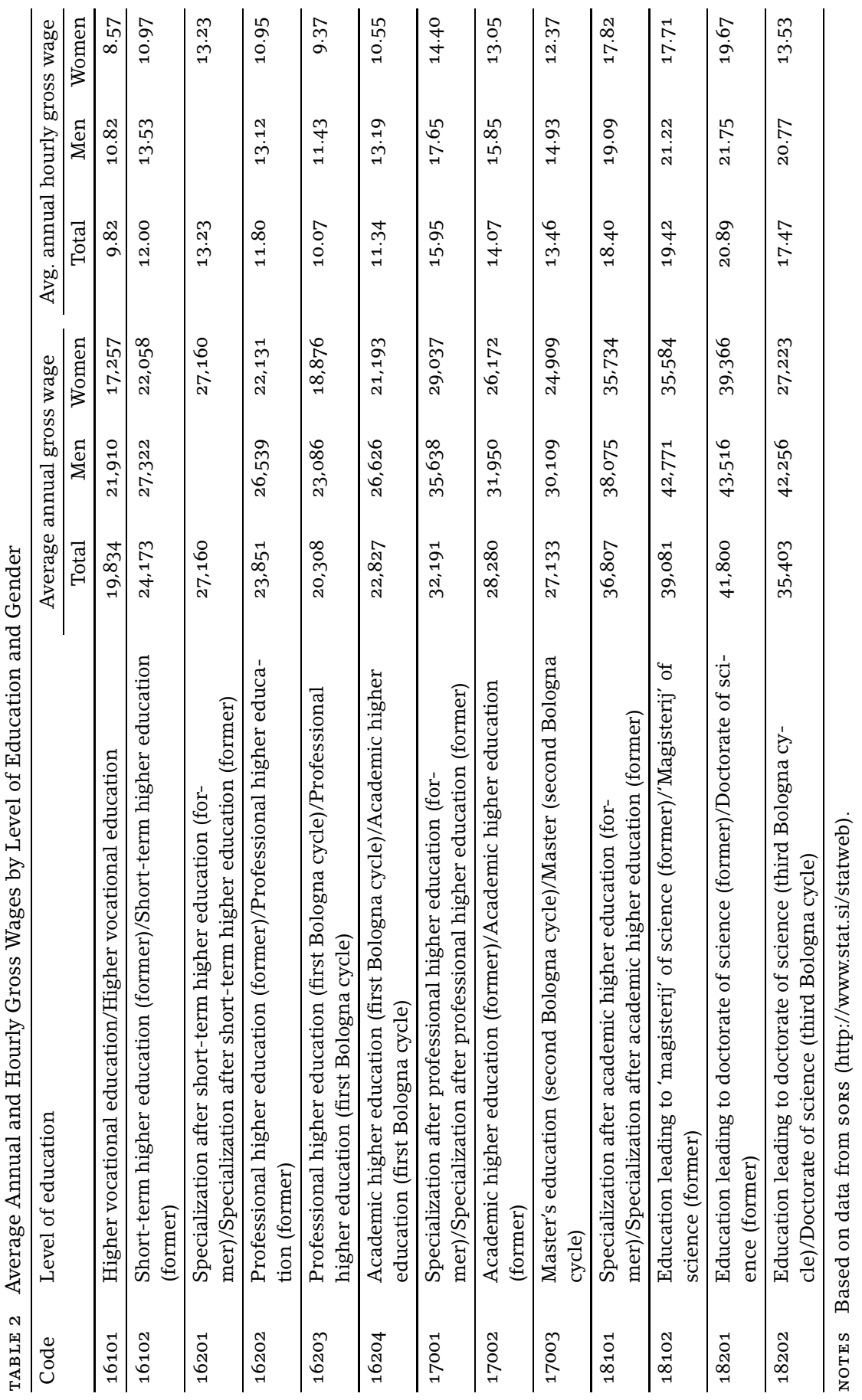


TABLE 3 Average Annual and Hourly Gross Wages by Field of Education and Gender

\begin{tabular}{lrrrrrrrr}
\hline Code & \multicolumn{2}{c}{ Average annual gross wage } & & \multicolumn{3}{c}{ Average annual hourly gross wage } \\
\cline { 2 - 4 } \cline { 7 - 8 } & Total & Men & Women & & Total & Men & Women \\
\hline 1 & 23,722 & 24,849 & 23,546 & & 11.97 & 12.53 & 11.89 \\
2 & 24,629 & 26,750 & 23,764 & & 12.38 & 13.43 & 11.95 \\
3 & 26,279 & 31,047 & 24,003 & & 13.06 & 15.42 & 11.93 \\
4 & 31,434 & 32,178 & 30,136 & & 15.63 & 15.99 & 14.99 \\
5 & 28,261 & 29,230 & 24,078 & & 13.99 & 14.46 & 11.96 \\
6 & 25,288 & 26,149 & 24,287 & & 12.60 & 13.01 & 12.11 \\
7 & 30,985 & 40,393 & 28,805 & & 15.10 & 19.67 & 14.04 \\
8 & 22,774 & 24,711 & 19,044 & & 11.27 & 12.22 & 9.45 \\
9 & 33,873 & 39,419 & 29,764 & & 16.88 & 19.60 & 14.85 \\
\hline
\end{tabular}

NотеS 1 -education, 2 -humanities and arts, 3 - social sciences, business and law, 4 - science, 5 - engineering, manufacturing and construction, 6 - agriculture, 7 - health and welfare, 8 - services, 9 - not known or unspecified by broad field. Based on data from sors (http://www.stat.si/statweb).

The logarithmic distribution of wages through the years and educational groups is well estimated by the sum of linear education function and quadratic functions of work experience. Heckman and Polachek $(1974,350)$ tried to find alternatives of wages transformation and found out that the Box-Cox logarithmic transformation of wages is the best. Probably as important as other causes is also the reason that the logarithmic transformation is very convenient for interpretation. Selecting the time frame through which we measure wages is often required as mandatory. Some databases contain the annual wages, while others contain the hourly or the weekly wages. Since people with higher education tend to work more, we expect higher returns of education for the weekly or the annual earnings, compared with the hourly wages. In this article we want to verify this.

Card (1999) concludes that the understanding of the individual wages of persons is very important for the society because it answers the question about the foundations of human standard. Understanding the impact of the factors which determine wages allows policy-makers to develop plans that promote economic growth, reduce poverty and enable country's opportunities for growth and development. Human capital theory focuses on the individual investments in human capital, which increase wages. Even workers with relatively small capacities have benefits through education and experience. 
The model, which was used in the analysis, is slightly augmented from the above-presented and has the following form.

AUGMENTED MINCER EQUATION

$$
\begin{aligned}
\ln w_{i}= & \beta_{\mathrm{o}}+\beta_{1} \text { traj }_{i}+\beta_{2} \text { pot_i } i_{i}+\beta_{3} \text { pot_i }_{i}^{2}+\beta_{4} \text { stbrez }_{i} \\
& +\beta_{5} D_{s p o l, i}+\beta_{6} D_{\text {sektor }, i} \\
& +\sum_{j=1}^{J} \gamma_{j} D_{j, i}+\sum_{k=1}^{K} \eta_{k} D_{k, i}+\sum_{l=1}^{L} \lambda_{l} D_{l, i}+\varepsilon_{i},
\end{aligned}
$$

where variable $\ln w_{i}$ represents the natural logarithm of wages of the person $i$, traj $_{i}$ is the length of time a person needed to obtain the level of education, pot $i_{i}$ is the potential work experience, the variable $s_{t b r e z}$ indicates the unemployment rate for the level of education obtained by the person, $D_{\text {spol }}$ in $D_{\text {sektor }}$ are dummy variables with a value of 1 if the person is female and if the person is employed in the public sector. $D_{j}$ is a dummy variable that indicates the activity $(j)$ of the employer. Similarly, $D_{k}$ in $D_{l}$ indicates the field $(k)$ of educational attainment and region $(l)$.

We can notice that the model contains many dummy variables. Unlike our predecessors, who divided the population (i. e. sample) into several subsets (sub samples) and evaluated them separately, we decided to use only one function.

The correctness of the specification of the model was tested with Ramsey reset test, which is connected to the functional form of the model. The test results have shown that the model function is correctly specified in all cases of the dependent variable.

\section{Results}

When interpreting the results we will focus primarily on the private returns of education, work experience and other socio-demographic characteristics causing wage differentials. The results obtained will be compared with a male person employed in the Osrednjeslovenska statistical region with Academic higher education (former) in the field of social sciences, business and law. Region, activity and field of education were chosen on the frequency basis - this is where the most people with tertiary level of education are employed.

As expected, the data shows that work experience and the length of schooling have a positive impact on the wage amounts. We observed that women earn significantly less than men. As regards activities, all sections except in Real estate activities (L), Professional, 
scientific and technical activities (M) and Administrative and support service activities $(\mathrm{N})$, have higher private returns on wages than Education (P). Private returns were the highest in the activities of Mining and quarrying (B), Electricity, gas, steam and air conditioning supply (D) and Financial and insurance activities (K).

It is worth mentioning that the impact of the public sector was negative until the inclusion of dummy variables relating to activities. After the inclusion of these variables in the model the returns become positive. In general it is believed that the public sector wages are higher than those in the private sector. Official findings, according to the statistical survey Structure of Earnings Statistics, prove this. In 2011 (2012) the average monthly gross wages in the public sector amounted to EUR 1870 (EUR 1843) and in the private sector to EUR 1430 EUR (1462 EUR), but if we consider only tertiary education, the average monthly gross earnings in the public sector amounted to EUR 2362 EUR (2311 EUR) and in the private sector to EUR 2392 EUR (EUR 2396 EUR).

In the public sector the educational structure is quite different than in the private sector (the share of people with tertiary education in the public sector is significantly higher) and therefore the average wage there is higher. Since the analysed population in this paper consists only of people with tertiary education, the positive impact of the public sector is somewhat surprising.

Comparison of returns by the fields of education (KLASIUS-P) reveals that out of all the fields health and welfare has the highest impact on the wages and agriculture has the lowest impact. As regards regions, as expected, the Osrednjeslovenska statistical region has the greatest impact on wages, however, the Notranjsko-kraška statistical region, somewhat unexpectedly, shows among all other regions statistically significantly lower impact on the wage amounts.

Low values of the determination coefficients indicates that not all relevant factors that affect the wage determination of an individual are covered. It is clear that the individual's earnings are defined through very heterogeneous factors. Let us mention just the impact of the enterprise - two very similarly educated individuals who perform substantially similar work and are employed in two different enterprises (even within the same industry) receive significantly different wages.

Other factors that could be included in the calculation for such an extensive database are unfortunately not available. Low values of the determination coefficient can also be observed in other studies, more often they are not even mentioned. 
TABLE 4 Regression Coefficients Estimates of the Model

\begin{tabular}{|c|c|c|c|c|c|c|c|c|c|}
\hline (1) & (2) & (3) & (4) & (5) & $(1)$ & $(2)$ & (3) & (4) & (5) \\
\hline $\mathrm{RMSE}_{-}$ & 0.378 & 0.323 & 0.378 & 0.323 & Skis & 0.016 & 0.025 & 0.017 & 0.025 \\
\hline Intercept & 8.004 & 7.866 & 0.386 & 0.252 & klas_p1 & 0.048 & 0.049 & 0.061 & 0.060 \\
\hline pot_i & 0.048 & 0.045 & 0.048 & 0.045 & klas_p2 & -0.088 & -0.071 & -0.079 & -0.064 \\
\hline pot_i2 & -0.001 & -0.001 & -0.001 & -0.001 & klas_p $p_{4}$ & 0.049 & 0.049 & 0.054 & 0.052 \\
\hline Traj & 0.110 & 0.090 & 0.110 & 0.091 & klas_p5 & - & 0.010 & 0.009 & 0.012 \\
\hline stBrez_2011 & -0.020 & -0.017 & -0.020 & -0.017 & klas_p6 & -0.103 & -0.077 & -0.101 & -0.077 \\
\hline spol1 & -0.153 & -0.133 & -0.150 & -0.132 & klas_p $p_{7}$ & 0.241 & 0.205 & 0.245 & 0.207 \\
\hline$s k d \_a$ & 0.092 & 0.081 & 0.067 & 0.054 & klas_p8 & -0.032 & -0.024 & -0.031 & -0.025 \\
\hline$s k d \_b$ & 0.352 & 0.297 & 0.331 & 0.279 & klas_p9 & 0.029 & 0.033 & 0.034 & 0.036 \\
\hline$s k d \_c$ & 0.167 & 0.143 & 0.151 & 0.127 & reg1 & -0.073 & -0.055 & -0.072 & -0.055 \\
\hline$s k d \_d$ & 0.316 & 0.271 & 0.290 & 0.246 & reg2 & -0.088 & -0.073 & -0.087 & -0.072 \\
\hline$s k d \_e$ & 0.195 & 0.170 & 0.173 & 0.149 & reg3 & -0.091 & -0.076 & -0.091 & -0.075 \\
\hline$s k d \_f$ & 0.117 & 0.090 & 0.109 & 0.084 & $\mathrm{reg}_{4}$ & -0.083 & -0.067 & -0.082 & -0.067 \\
\hline$s k d \_g$ & 0.095 & 0.071 & 0.096 & 0.071 & reg5 & - & - & - & - \\
\hline$s k d \_h$ & 0.180 & 0.150 & 0.145 & 0.114 & reg6 & -0.052 & -0.037 & -0.052 & -0.037 \\
\hline$s k d \_i$ & - & - & 0.050 & 0.048 & reg7 & - & - & - & - \\
\hline$s k d j$ & 0.121 & 0.101 & 0.110 & 0.089 & regg & -0.067 & -0.051 & -0.066 & -0.050 \\
\hline$s k d \_k$ & 0.254 & 0.216 & 0.257 & 0.218 & reg1o & -0.122 & -0.096 & -0.122 & -0.095 \\
\hline$s k d_{-} l$ & -0.059 & -0.053 & -0.054 & -0.048 & reg11 & -0.082 & -0.059 & -0.081 & -0.058 \\
\hline$s k d \_m$ & - & - & - & - & reg12 & -0.070 & -0.057 & -0.069 & -0.056 \\
\hline$s k d \_n$ & -0.065 & -0.056 & -0.048 & -0.040 & $\mathrm{MSE}_{-}$ & 0.14291 & 0.10454 & 0.14289 & 0.10453 \\
\hline$s k d \_o$ & - & - & - & - & ${ }_{-} \mathrm{RSQ}$ & 0.34775 & 0.34893 & 0.34510 & 0.34607 \\
\hline$s k d \_q$ & 0.021 & 0.014 & -0.014 & -0.021 & ${ }_{-} \mathrm{AIC}_{-}$ & -254959 & -295934 & -254974 & -295941 \\
\hline$s k d \_r$ & - & - & - & - & ${ }_{-} \mathrm{BIC}_{-}$ & -254957 & -295932 & -254972 & -295939 \\
\hline$s k d \_s$ & - & - & 0.060 & 0.058 & & & & & \\
\hline
\end{tabular}

NOTES Column headings are as follows: (1)_DEPVAR_, (2) gross yearly wages, (2) net yearly wages, (3) gross wages per hour, (4) net wages per hour.

\section{Conclusions}

In this paper we discovered that there are significant differences in the amounts of wages with regard to the level and field of education. Additionally, we can not confirm previously established facts (Card 1999), that private returns of the fields of education are constant. The results of the analysis show the greatest returns with regard to the field of education (KLASIUS-P) in the field of health and welfare and the smallest in the field of agriculture. The results are based on year 2011 data which corresponds with the economic downturn in Slovenia.

Among statistical regions the figures are as expected. The highest returns of education on wages are observed for the Osrednjeslovenska statistical region. The Notranjsko-kraška statistical region has, somewhat unexpectedly, the lowest returns on wages. Compared to Osrednjeslovenska statistical region, all other regions have statistically significant lower impact on wages.

No matter whether we use the annual wages or the hourly wages, the returns of gender are statistically significant and in favour of 
men. We may add that in the case of using earnings per hour we expected at least somewhat smaller returns for men, which is not the case.

The impact of activities is also significant. The highest (positive) returns are observed in Mining. The least favourable impact was in Real estate activities. This results may be influenced by macroeconomic environment and should therefore be interpreted with caution. In the future it would be appropriate to verify the role of different assessment methods and check other estimators. The database for this analysis was cross-sectional. A database extension with data for more years (to include the role of time) would be reasonable for future research in order to eliminate effects of business cycles and other factors which may influence the results.

\section{References}

Ahčan, A., S. Polanec, and M. Kozamernik. 2008. 'Donosnost terciarnega izobraževanja v Sloveniji v obdobju 1994-2004.' Research report, Faculty of Management, Koper.

Ahčan, A., S. Polanec, and N. Trunk-Širca. 2006. 'Analiza donosnosti terciarnega izobraževanja v Sloveniji.' Research report, Faculty of Management, Koper.

Angris, J., and A. Krueger. 1991. 'Does Compulsory School Attendance Affect Schooling and Earnings?' The Quarterly Journal of Economics 106 (4): 979-1014.

Barro, R. J., and X. Sala-i-Martin, X. 2003. Economic Growth. 2nd ed. Cambridge, MA: мIт Press.

Bartolj, T., A. Ahčan, A. Feldin, and S. Polanec. 2012. 'Evolution of Private Returns to Tertiary Education during Transition: Evidence from Slovenia.' LIcos Discussion Paper Series 314/2012, University of Leuven, Leuven.

Becker, G. S. 1993. Human Capital: A Theoretical and Empirical Analysis, with Special Reference to Education. 3rd ed. Chicago: The University of Chicago Press.

Bevc, M. 1993. 'Rates of return of Investment in Education in Former Yugoslavia in the 1970 and 1980 s by Region.' The Economics of Education Review 12 (4): 325-43.

Boarini, R., and H. Strauss. 2010. 'What is the Private Return to Tertiary Education? New Evidence from 21 ofcd Countries.' ofcd Journal: Economic Studies. https://www.oecd.org/eco/labour/49850154.pdf

Buonanno, P., and D. Pozzoli. 2009. 'Early Labour Market Returns to College Subjects'. Labour 23 (4): 559-88.

Card, D. 1999. 'The Causal Effect of Education on Earnings.' In Handbook of Labor Economics, edited by O. Ashenfelter and D. Card, 1801-63. Amsterdam: Elsevier. 
Conneely, K., and R. Uusitalo. 1997. 'Estimating Heterogeneous Treatment Effects in the Becker Schooling Model.' Unpublished Discussion Paper, Princeton University, Princeton, NJ.

Divjak. M. 2011. 'Methodological Explanations: Structure of Earnings statistics, Slovenia.' http://www.stat.si/StatWeb/Common/

PrikaziDokument.ashx?IdDatoteke $=8333$

Ehrenberg, R. G., and R. S. Smith. 2000. Modern Labor Economics. 7th ed. Reading, mA: Addison-Wesley.

Harmon, C., I. Walker, and N. Westergaard-Nielsen. 2001. Education and Earnings in Europe. Aldershot: Edward Elgar.

Heckman, J., and S. Polachek. 1974. 'Empirical Evidence on the Functional Form of the Earnings-Schooling Relationship.' Journal of the American Statistical Association 69:350-4.

Kozmelj, A. 2014. 'Methodological Explanations: Graduates from Tertiary Education, Slovenia.' http://www.stat.si/StatWeb/Common/ PrikaziDokument.ashx?IdDatoteke $=8352$

Livanos, I., and K. Pouliakas. 2008. 'Returns to Education by Academic Discipline in the Greek Labour Market.' MPRA Paper 14159, Munich Personal RePEc Archive, Munich. http://mpra.ub.uni-muenchen .de/14159/1/MPRA_paper_14159.pdf

- 2009. 'Wage Returns to University Disciplines in Greece: Are Greek Higher Education Degrees Trojan Horses?' MPRA Paper 18821, Munich Personal RePEc Archive, Munich. http://mpra.ub.uni -muenchen.de/18821/1/MPRA_paper_18821.pdf

Mincer, J. A. 1974. Schooling, Experience, and Earnings. Cambridge, mA: National Bureau of Economic Research.

Münich, D., J. Svejnar, and K. Terrell. 2005. 'Returns to Human Capital under the Communist Wage Grid and During the Transition to a Market Economy.' The Review of Economics and Statistics 87 (1): 10023.

Orazem, P. F., and M. Vodopivec. 1994. 'Winners and Losers in Transition: Returns to Education, Experience and Gender in Slovenia.' Policy Research Working Paper 1342, The World Bank, Washington, DC.

- 1997. 'Value of Human Capital in Transition to Market: Evidence from Slovenia.' European Economic Review 41 (3): 893-903.

Petek, D. 2016. 'Vpliv terciarne izobrazbe na višino plač v Republiki Sloveniji.' Master thesis, University of Maribor, Maribor.

Polachek, S. W. 2007. 'Earnings Over the Lifecycle: The Mincer Earnings Function and its Applications.' IzA Discussion Paper 3181, Institute of Labor Economics, Bonn.

Stanovnik, T. 1997. 'The Returns to Education in Slovenia.' Economics of Education Review 16 (4): 443-9.

Vodopivec, M. 2004. 'Labor Market Developments in the 1990s.' In Slovenia: From Yugoslavia to the European Union, edited by M. 
Mrak, M. Rojec, and C. Silva-Jáuregui, 293-314. Washington, Dc: The World Bank.

. 2006. 'The Evolution and Determinants of Earnings in Slovenia.' Iв revija 40 (1-2): 37-50.

Walker, I., and Y. Zhu. 2010. 'Differences by Degree: Evidence of the Net Financial Rates of Return to Undergraduate Study for England and Wales.' IzA Discussion Paper 5254, Institute of Labor Economics, Bonn. 